\title{
Depositional and erosional landforms in the Lothar Khola watershed, Central Nepal
}

\author{
V. Dangol and P. D. Ulak \\ Department of Geology, Tri-Chandra Campus, Tribhuvan University, Kathmandu, Nepal
}

\begin{abstract}
The high intensity rainfall of 19 and 20 July 1993 triggered off a large number of mass movements in the Lothar Khola watershed of Central Nepal. Most of the slides were reactivated on highly fractured and weathered rocks during the downpour. Among more than 40 landslides encountered in the watershed, the large rockslides were found at Purbangkhani, Karse, and Loling. A detailed study of landslide distribution in the watershed revealed that most of the landslides (about $65 \%$ of the total landslide area) occurred on slopes ranging from 26 to $40^{\circ}$ These slopes were nearly equal to or a little steeper than the internal friction angle of constituting soil or rock mass. According to land use pattern, more than two thirds of the landslide area fell in the forestland and there were no landslides on the grassland. Similarly, rockslides were concentrated (about $53 \%$ of the total rockslide area) on slopes covered by slates and phyllites. On the other hand, an overwhelming majority of soil slides (more than $85 \%$ of the total soil slide area) occurred on residual soils. Debris flows were also very common in the Lothar Khola watershed. During the debris flow, from 1 to $3 \mathrm{~m}$ deepening of the riverbed was observed in many erosional zones whereas the sediment accumulation reached up to $4 \mathrm{~m}$ in the depositional zones.
\end{abstract}

\section{INTRODUCTION}

The torrential rains of 19 and 20 July 1993 devastated the Lothar Khola watershed. The watershed lies on the southern slopes of the Mahabharat Range in the Central Development Region of Nepal and occupies about $170 \mathrm{~km}^{2}$ of area. The Lothar Khola is formed by nine small streams flowing essentially from north to south (Fig. 1). Between 19 and 20 July 1993 , the maximum 24-hour rainfall of $540 \mathrm{~mm}$ was recorded at Tistung (the

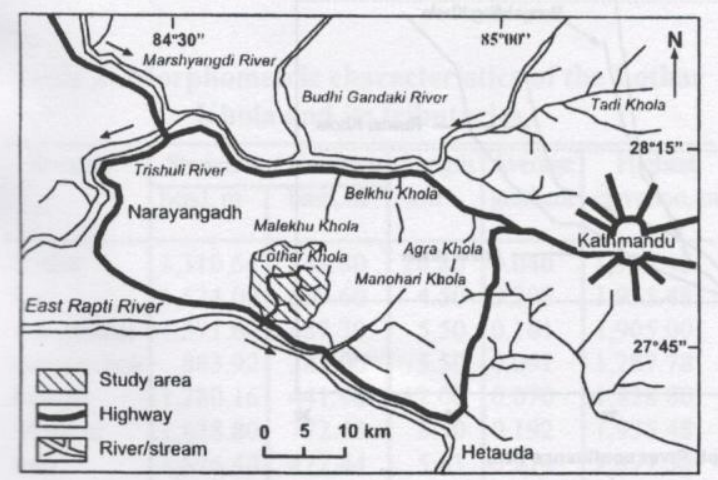

Fig. 1: Location map of the study area
Mahabharat Range). It was also the highest 24-hour rainfall ever recorded in Nepal (DHM 1993). The highest hourly rainfall intensity was observed on 19 July. The torrential rains triggered off a large number of landslides and debris flows in that area. The paper describes the geological and geomorphological features of the watershed together with the nature and types of mass movements. It also relates the mass movements with such factors as rock and soil types, slope angle, aspect, and land use.

\section{WATERSHED CHARACTERISTICS}

The major streams of the watershed are the Lothar Khola, Kali Khola, Bangshiling Khola, Ganwarchok Khola, Rewati Khola, Shankar Khola, Imti Khola, and Pangthali Khola. The watershed is fan-shaped, having dendritic and radial drainage patterns (Fig. 2) with a form factor of 0.77 . The compact coefficient of the basin is 1.21 .

The bed gradient is very high $\left(15^{\circ}\right)$ towards the upper reaches of streams. It decreases significantly along the middle reaches, and then becomes almost flat (Fig. 3). Figure 4 shows the slope conditions in the watershed. The slopes are classified into the 


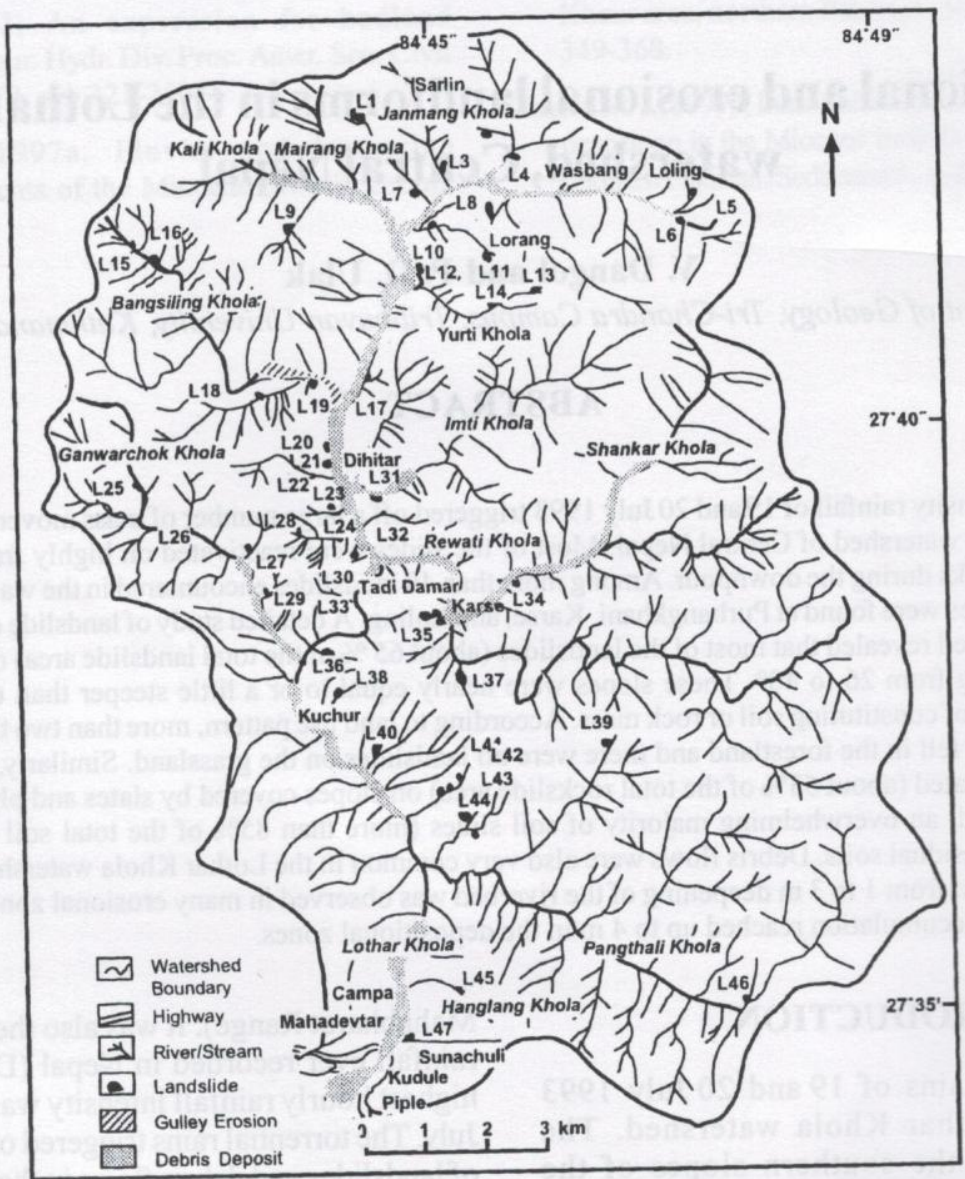

Fig. 2: Drainage map of the Lothar Khola watershed. Locations of landslides larger than $500 \mathrm{~m}^{2}$ are also indicated.

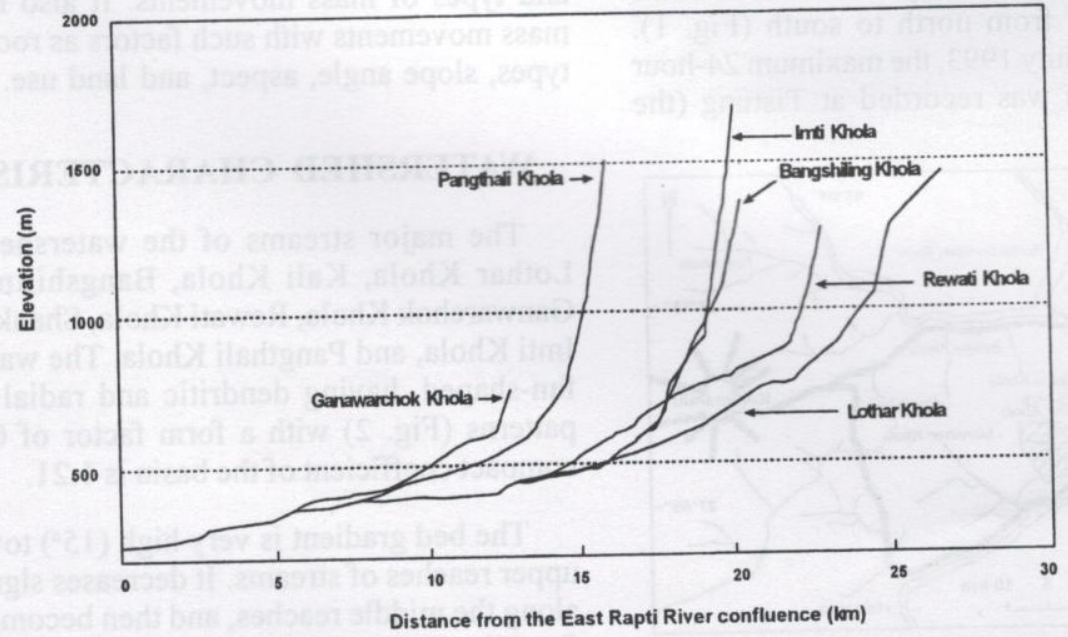

Fig. 3: Longitudinal profiles of the main streams from the Lothar Khola watershed 
following five categories: less than $5^{\circ}, 5-15^{\circ}, 16-25^{\circ}$, $26-40^{\circ}$, and more than $40^{\circ}$. About two thirds of the watershed belongs to slopes above $25^{\circ}$ (Table 1 ). Flat and gentle areas are very limited. The other morphometric characteristics of the watershed are given in Table 2. The streambed elevation at the outlet of the watershed is $300 \mathrm{~m}$ and the highest point in the basin has an elevation of about $2000 \mathrm{~m}$.

Table 1: Area covered by various slope categories in the Lothar watershed

\begin{tabular}{c|c|c}
\hline Slope, degree & Area, $\mathrm{km}^{2}$ & Percentage \\
\hline$<5$ & 0.8 & 0.47 \\
$5-15$ & 9.5 & 5.62 \\
$16-25$ & 47.5 & 28.11 \\
$26-40$ & 74.2 & 43.91 \\
$>40$ & 37.0 & 21.89 \\
\hline
\end{tabular}

\section{Rocks}

The study area lies on the southern flank of the doubly plunging Mahabharat Synclinorium. It is made up of low-to medium-grade metamorphic rocks of the Lesser Himalaya and sedimentary rocks of the Siwaliks (Fig. 5).

The Siwaliks form a distinct foothill zone containing soft mudstones, sandstones, and conglomerates. Generally, the Main Frontal Thrust (MFT) marks the southern boundary of the Siwaliks, whereas their northern border is sharply marked by the Main Boundary Thrust (MBT). The Siwalik Group is divided into the Lower, Middle, and the Upper Siwaliks. The Middle Siwaliks are further subdivided into the Lower Member $\left(\mathrm{MS}_{1}\right)$ and Upper Member $\left(\mathrm{MS}_{2}\right)$.

Table 2: Morphometric characteristics of the Lothar Khola and its tributaries

\begin{tabular}{|c|c|c|c|c|c|}
\hline \multirow[t]{2}{*}{ Streams } & \multicolumn{2}{|c|}{ Stream bed elevation } & \multirow{2}{*}{$\begin{array}{l}\text { Length } \\
\mathrm{km}\end{array}$} & \multirow{2}{*}{$\begin{array}{l}\text { Average } \\
\text { gradient }\end{array}$} & \multirow{2}{*}{$\begin{array}{c}\text { Highest } \\
\text { elevation, } \mathrm{m}\end{array}$} \\
\hline & head, $m$ & base, $m$ & & & \\
\hline Lothar & $1,310.64$ & 243.80 & 26.80 & 0.040 & $1,935.48$ \\
\hline Kali & $1,524.00$ & 609.60 & 4.50 & 0.203 & $1,935.48$ \\
\hline Bangsiling & $1,371.60$ & 487.70 & 5.50 & 0.161 & $1,905.00$ \\
\hline Ganwarchok & 883.92 & 381.00 & 5.50 & 0.091 & $1,287.78$ \\
\hline Rewati & $1,280.16$ & 441.96 & 12.00 & 0.070 & $1,828.80$ \\
\hline Shankar & $1,828.80$ & 772.40 & 5.50 & 0.192 & $1,935.48$ \\
\hline Imti & $1,676.40$ & 472.44 & 5.63 & 0.214 & $1,897.38$ \\
\hline Pangthali & $1,524.00$ & 365.80 & 10.00 & 0.116 & $1,927.86$ \\
\hline
\end{tabular}

The Lesser Himalayan Zone lies to the north of the MBT. The Lesser Himalayan rocks are represented by the Nawakot Complex and the Kathmandu Complex (Table 2). The rocks of the Kathmandu Complex are thrust over the Nawakot Complex along the Mahabharat Thrust (MT).

The Nawakot Complex consists of phyllites, slates, quartzites, limestones, and dolomites. It is subdivided into the Lower and Upper Nawakot Groups, the two being separated by a disconformity (Table 2). In the study area, only the rocks of the Upper Nawakot Group are present (Fig. 5).

The Kathmandu Complex is subdivided into the Bhimphedi Group that comprises medium-grade metamorphic rocks (i.e. schists, quartzites, and gneisses), and the Phulchowki Group of sedimentary and low-grade metamorphic rocks (Table 2). In the study area, only the Bhimphedi Group is present.

\section{Soils}

The soils found in the study area are of following three types: (1) alluvial, (2) colluvial, and (3) residual. Their distribution is shown in Fig. 5.

Alluvial soils are found sporadically in the study area. They are observed along the middle reaches of the Lothar Khola and its main tributaries as well as near the confluence of the Lothar Khola and East Rapti River. The alluvial soils form alternating layers of gravel, sand, and fines, and their thickness generally does not exceed $10 \mathrm{~m}$.

Colluvial soils are found mainly in the upper reaches of the Kali Khola and Imti Khola, and at Dihitar. The total area covered by them is about 2 $\mathrm{km}^{2}$. Generally, the colluvial soils are thinner on the upper slopes and thicker near the foothills.

Residual soils occupy an extensive area. They are found along the upper reaches of the Lothar Khola, Bangsing Khola, Ganwarchok Khola, Rewati Khola, and Imti Khola as well as at Charkill, Sillingi, Siladhani, and Dhusabagar. The residual soils are derived mainly from phyllites, calcareous schists, and mica schists. They are red to light brown in colour and cover an area of about $20 \mathrm{~km}^{2}$.

\section{Land Use}

Well-cultivated areas with many villages occupy the middle portion of the watershed whereas trees 


\section{Dangol and P.D. Ulak}

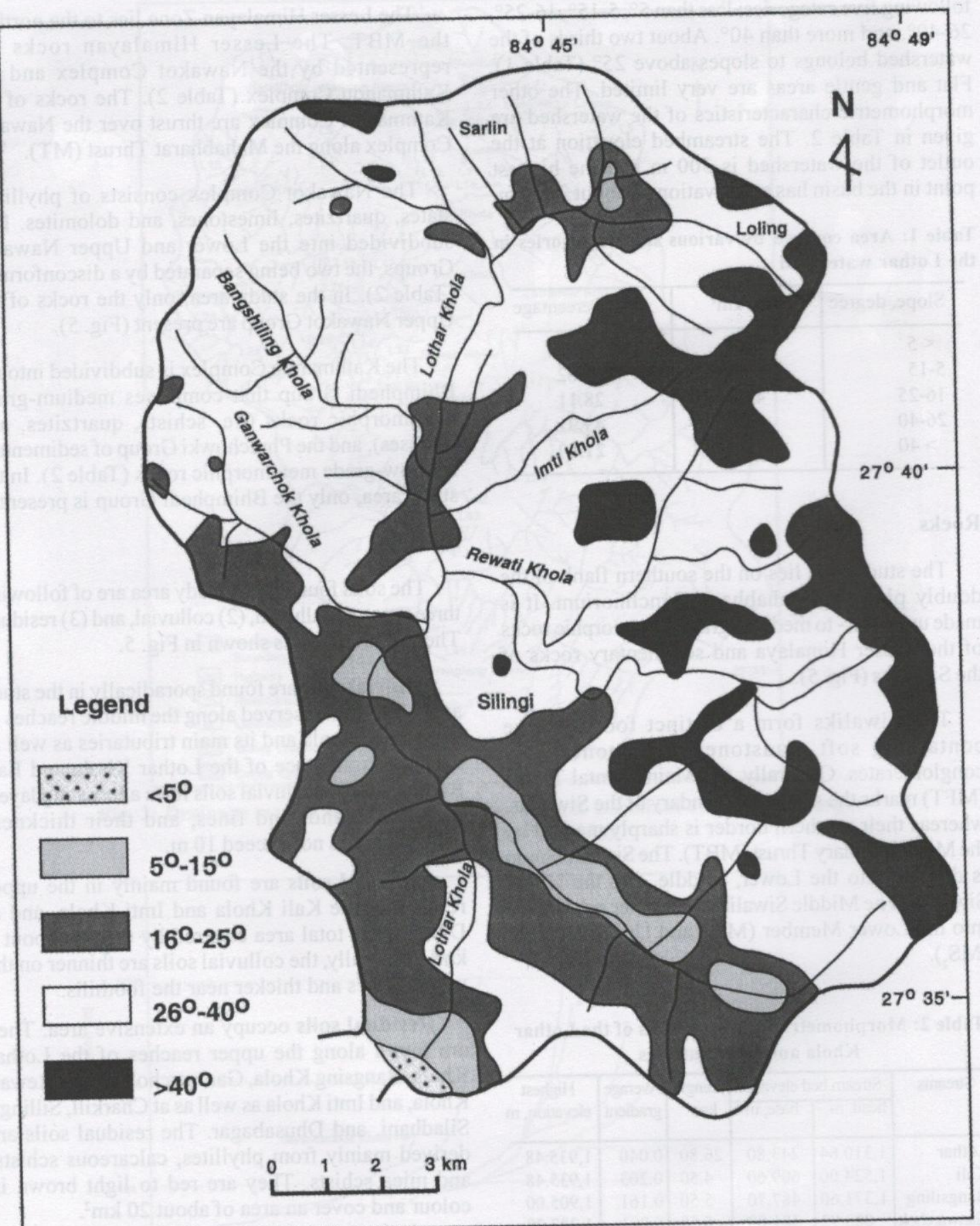

Fig. 4: Slope map of the Lothar Khola watershed 
Depositional and erosional landforms in the Lothar Khola watershed, Nepal

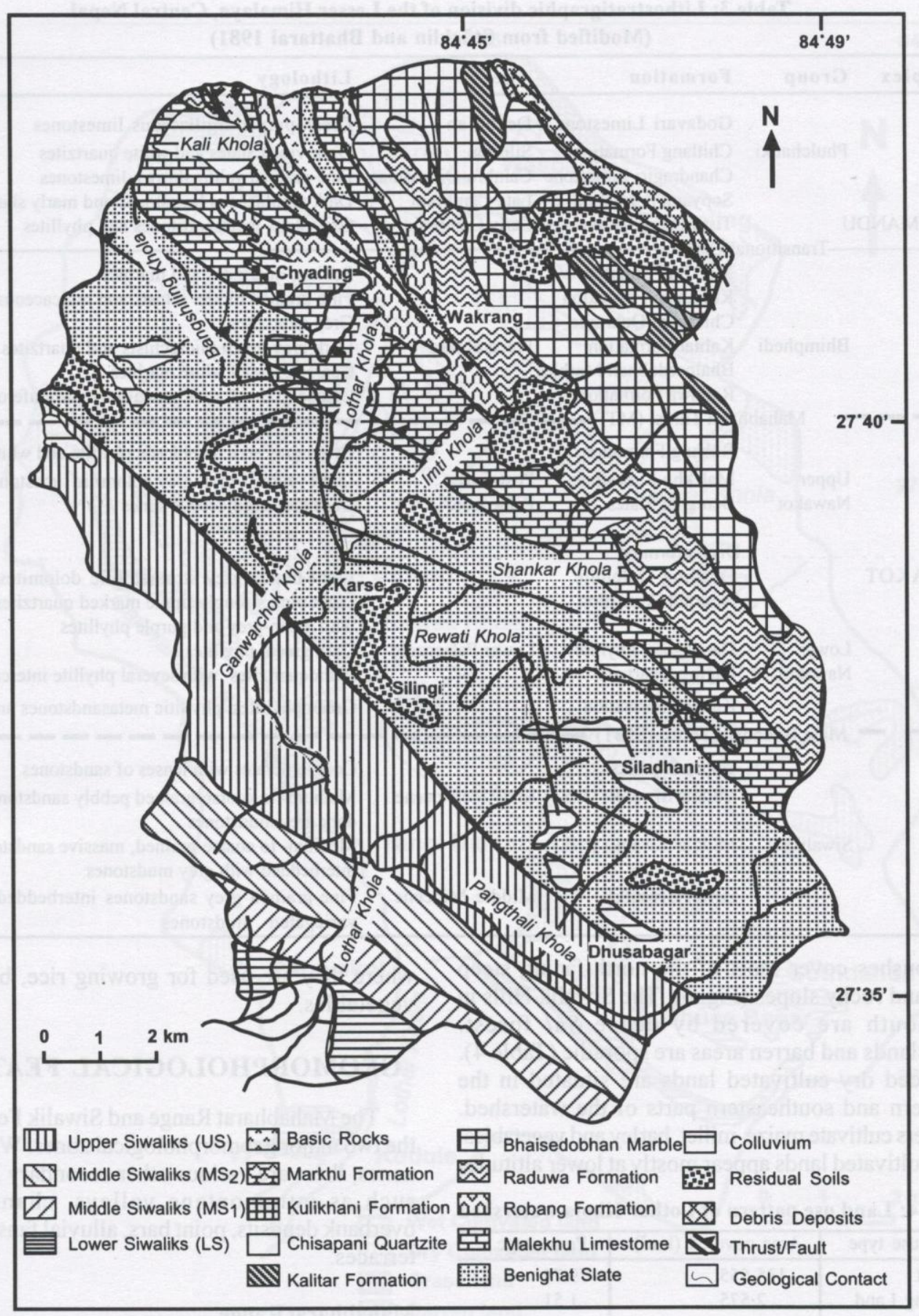

Fig. 5: Geological map of the Lothar Khola watershed 
Table 3: Lithostratigraphic division of the Lesser Himalaya, Central Nepal (Modified from Stöcklin and Bhattarai 1981)

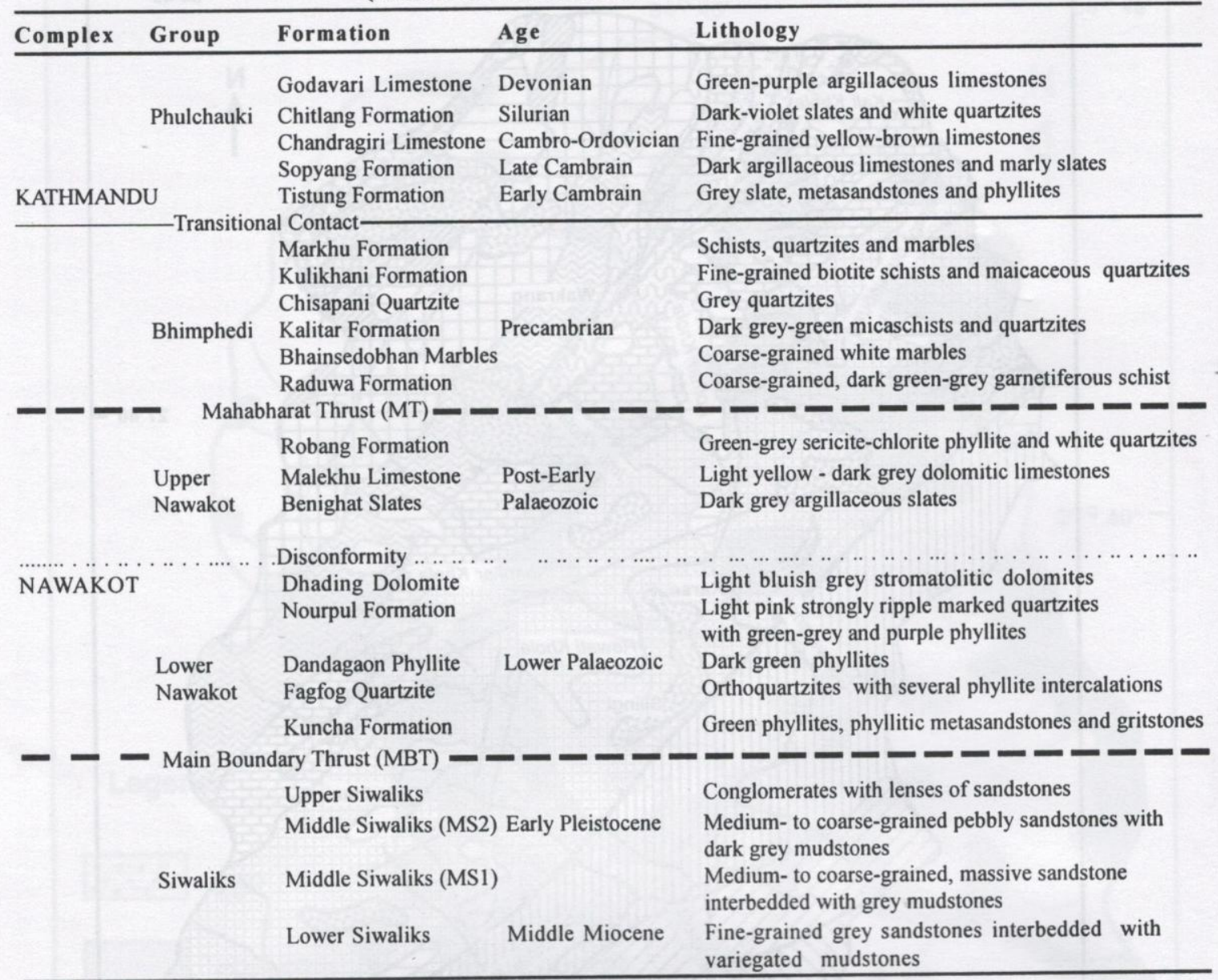

and bushes cover most of the north-facing steep hills and rocky slopes (Fig. 6). The Siwalik Hills in the south are covered by dense $S a l$ forest. Grasslands and barren areas are sporadic (Table 4). Terraced dry cultivated lands are situated in the northern and southeastern parts of the watershed. Farmers cultivate maize, millet, barley and vegetables. Wet cultivated lands appear mostly at lower altitudes

Table 4: Land use pattern of Lothar Khola watershed

\begin{tabular}{l|c|c}
\hline Land use type & Area covered $\left(\mathrm{km}^{2}\right)$ & Percentage \\
\hline Forest & 135.555 & 79.74 \\
Grazing Land & 2.575 & 1.51 \\
Wet Cultivation & 8.588 & 5.05 \\
Dry Cultivation & 22.707 & 13.36 \\
Barren Land & 0.575 & 0.34 \\
\hline Total & $\mathbf{1 7 0 . 0 0}$ & $\mathbf{1 0 0 . 0 0}$ \\
\hline
\end{tabular}

where they are used for growing rice, barley, and vegetables.

\section{GEOMORPHOLOGICAL FEATURES}

The Mahabharat Range and Siwalik Foothills are the two major geomorphological zones. Within these zones, there are various other secondary landforms such as intramontane valleys, channel bars, overbank deposits, point bars, alluvial fans, and river terraces.

\section{Mahabharat Range}

The Mahabharat Range lies between the MBT in the south and the Mid-hills in the north. The altitude of the Mahabharat Range varies from 2000 


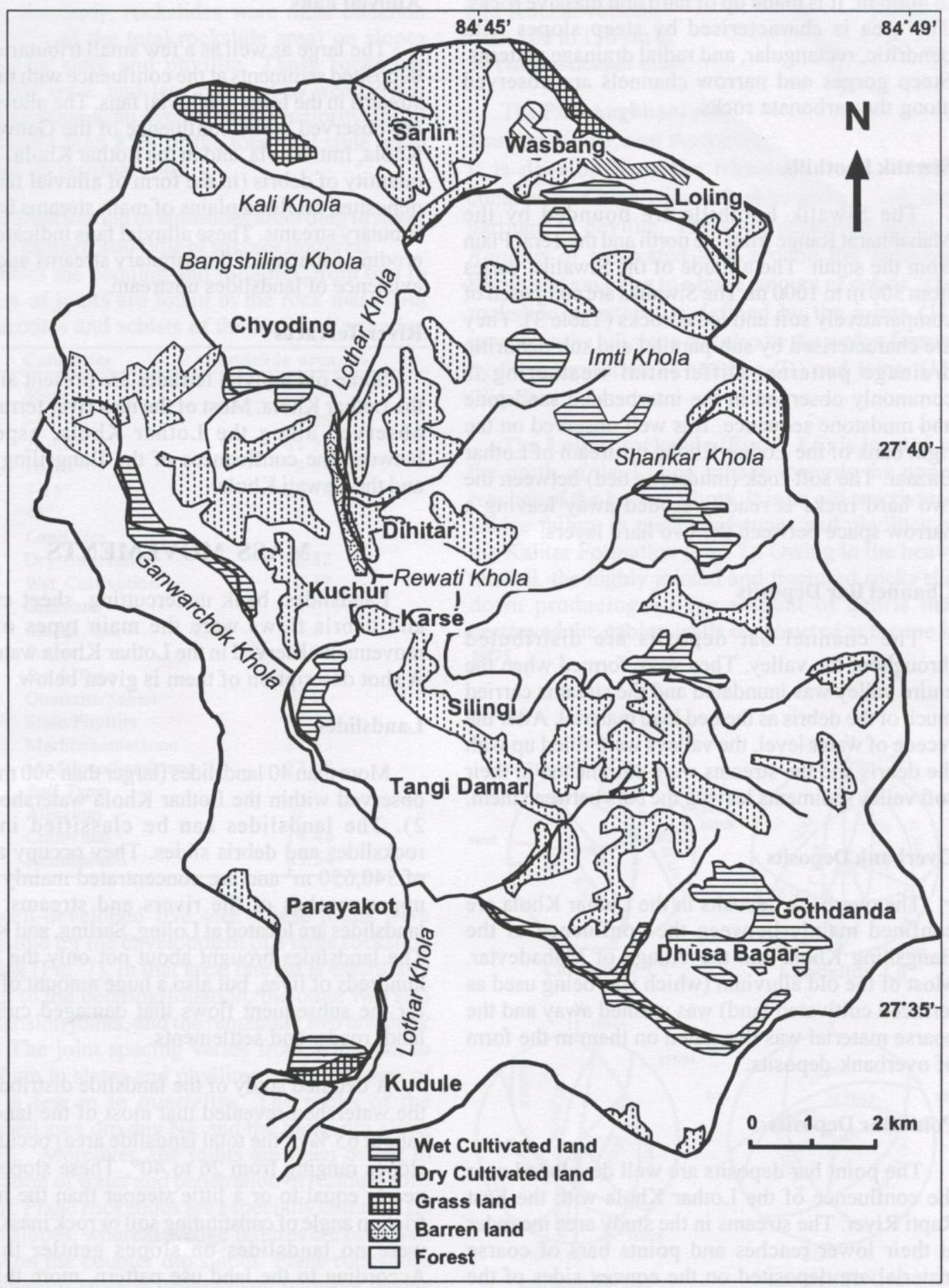

Fig. 6: Landuse map of the Lothar Khola watershed 
to $4000 \mathrm{~m}$. It is made up of hard and massive rocks. The area is characterised by steep slopes with dendritic, rectangular, and radial drainage patterns. Steep gorges and narrow channels are observed along the carbonate rocks.

\section{Siwalik Foothills}

The Siwalik Foothills are bounded by the Mahabharat Range from the north and the Terai Plain from the south. The altitude of the Siwaliks varies from $300 \mathrm{~m}$ to $1000 \mathrm{~m}$. The Siwaliks are composed of comparatively soft and loose rocks (Table 3 ). They are characterised by sub-parallel and sub-dendritic drainage patterns. Differential weathering is commonly observed in the interbedded sandstone and mudstone sequence. It is well observed on the right bank of the Lothar Khola, upstream of Lothar Bazaar. The soft rock (mudstone bed) between the two hard rocks is readily eroded away leaving a narrow space between the two hard layers.

\section{Channel Bar Deposits}

The channel bar deposits are distributed throughout the valley. They were formed when the entire valley was inundated and the streams carried much of the debris as the bed load material. After the recede of water level, the valleys were filled up with the debris and the streams were entrenched in their soft valley sediments leaving the bars between them.

\section{Overbank Deposits}

The overbank deposits in the Lothar Khola are confined mainly between the confluence of the Bangsiling Khola and the village of Mahadevtar. Most of the old alluvium (which was being used as terraced cultivated land) was washed away and the coarse material was deposited on them in the form of overbank deposits.

\section{Point Bar Deposits}

The point bar deposits are well developed near the confluence of the Lothar Khola with the East Rapti River. The streams in the study area meander at their lower reaches and points bars of coarse material are deposited on the convex sides of the meanders. The bars grow gradually outwards the meander curve.

\section{Alluvial Fans}

The large as well as a few small tributaries have deposited sediments at the confluence with the trunk streams in the form of alluvial fans. The alluvial fans are observed at the confluence of the Ganwarchok Khola, Imti Khola, and in the Lothar Khola. A large quantity of debris (in the form of alluvial fans) was deposited on flood plains of main streams by many tributary streams. These alluvial fans indicate a high eroding capacity of the tributary streams and/or the existence of landslides upstream.

\section{River Terraces}

Some old alluvial terraces are present all along the Lothar Khola. Most of the new river terraces are observed along the Lothar Khola, especially between the confluences of the Bangsiling Khola and the Rewati Khola.

\section{MASS MOVEMENTS}

Landslides, bank undercutting, sheet erosion, and debris flows were the main types of mass movement observed in the Lothar Khola watershed. A shot description of them is given below.

\section{Landslides}

More than 40 landslides (larger than $500 \mathrm{~m}^{2}$ ) were observed within the Lothar Khola watershed (Fig. $2)$. The landslides can be classified into the rockslides and debris slides. They occupy an area of $340,650 \mathrm{~m}^{2}$ and are concentrated mainly on the upper reaches of the rivers and streams. Large landslides are located at Loling, Sarling, and Kuchur. The landslides brought about not only the loss of hundreds of lives, but also a huge amount of debris for the subsequent flows that damaged cultivated land, roads, and settlements.

A detailed study of the landslide distribution in the watershed revealed that most of the landslides (about $65 \%$ of the total landslide area) occurred on slopes ranging from 26 to $40^{\circ}$. These slopes were nearly equal to or a little steeper than the internal friction angle of constituting soil or rock mass. There were no landslides on slopes gentler than $5^{\circ}$. According to the land use pattern, more than two thirds of the landslide area fell in the forestland and there were no landslides on slopes covered by 


\section{Depositional and erosional landforms in the Lothar Khola watershed, Nepal}

grasses. Similarly, rockslides were most common (about $53 \%$ of the total rockslide area) on slopes covered by slate and phyllite. These rocks are potentially weak and less resistant to weathering. On the other hand, an overwhelming majority of soil slides (more than $85 \%$ of the total soil slide area) occurred on residual soils.

Table 5: Distribution of landslides according to slope, land use pattern and type of surface material

Besides the bedding and foliation, from two to four sets of joints are found in the rock mass. But the quartzites and schists of the Kalitar Formation

\begin{tabular}{lc}
\hline Categories & Landslide area, \% \\
\hline Slope & \\
$>40^{\circ}$ & 5.28 \\
$26-40^{\circ}$ & 65.35 \\
$16-25^{\circ}$ & 18.64 \\
$5-15^{\circ}$ & 10.76 \\
$<5^{\circ}$ & 0 \\
Land Use & 10.82 \\
Dry Cultivation & 10.32 \\
Wet Cultivation & 0 \\
Grassland & 3.6 \\
Barren land & 75.26 \\
Forest & \\
Rock Type & 9.36 \\
Quartzite/Schist & 53.13 \\
Slate/Phyllite & 14.53 \\
Marble/Limestone & 22.98 \\
Mudstone/Sandstone & 0 \\
Soil Type & 14.46 \\
Alluvium & 85.54 \\
Colluvium & \\
Residual soil &
\end{tabular}

have well-developed five sets. These joints were responsible for the development of a large rockslide at Loling (Fig. 7). In that area, one set is essentially parallel to the bedding/foliation, the other two sets are extension joints, and the remaining two are shear joints. The joint spacing varies from a few $\mathrm{cm}$ to tens of $\mathrm{cm}$ in slates and phyllites, and from tens of $\mathrm{cm}$ to a few $\mathrm{m}$ in quartzites. The rocks of the watershed area dip due NE and the faults run along NW-SE. Moreover, the joints are open owing to percolation of water and penetration of residual soils in them. Plane rockslides are especially common on the dip slopes, whereas wedge failures are observed mostly on the counter dip slopes. Plane rockslides are generally large in comparison with the wedge failures. Many tension cracks were seen, especially at the crowns of the Purbangkhani slide, Karse slide, and Kuchur rockslide. Frequently the cracks were from 100 to $150 \mathrm{~cm}$ deep. But some were wider than $50 \mathrm{~cm}$ and deeper than $2 \mathrm{~m}$.

The Purbangkhani rockslide (Plate 1) lies in the Janmang Khola, near the Sarling village (Fig. 2, L3). It is developed on the Bhainsedobhan Marble composed of highly jointed white marble with thin partings of phyllite. The slide destroyed about 7 Ropanis of cultivated land around the Janmang Khola and gave rise to a huge amount of debris. The rockslide geometry is defined by the joints (J1) parallel to the hill slope and also by the wedge formed by the intersection of bedding (B) and joints (J1) (Fig. 7).

The Loling rockslide (Fig. 2, L6) is located to the north of the Loling village towards the upper reaches of the Lothar Khola. It is an old reactivated wedge failure in meta-sandstones and phyllites of the Kalitar Formation (Fig. 7). Owing to the heavy rainfall, the highly jointed and fractured rocks slid down producing a huge amount of debris that destroyed the gabion walls constructed at the toe in 1975.
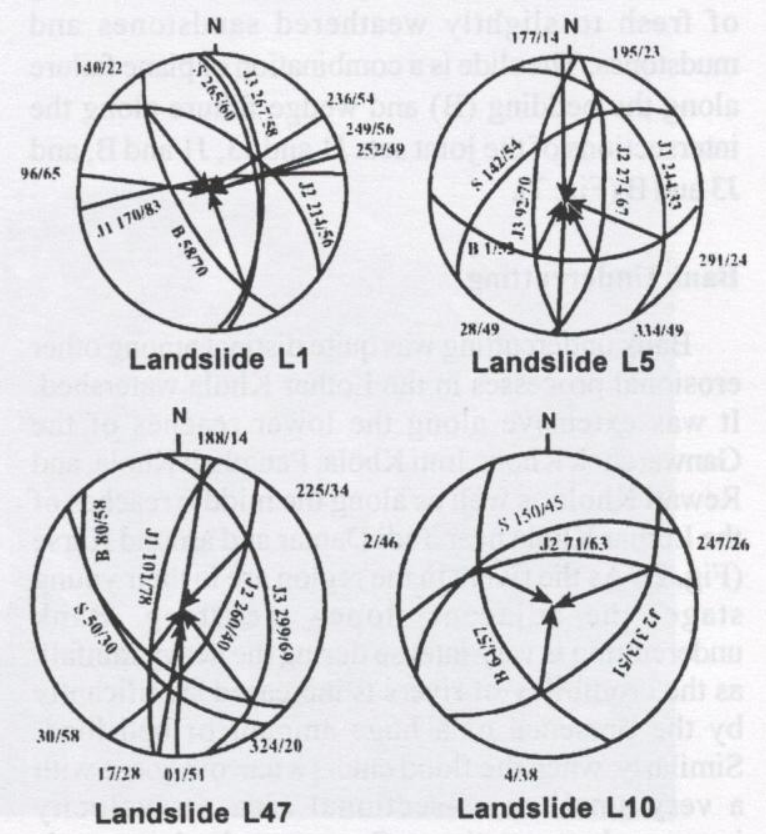

Fig. 7: Upper Hemispherical Stereographic projections of rock discontinuities from various landslides 
The Yurti rockslide (Fig. 2, L12) is observed on the left bank of the Lothar Khola, near the junction of the Yurti Khola with the Lothar Khola (Fig. 2). It is developed on fresh to slightly weathered quartzites with intercalation of phyllites and slates of the Robang Formation. The rocks are highly fractured and thinly bedded. The rockslide is a combination of plane failure along the joint $(\mathrm{J} 3)$ and wedge failures along the intersections of the joints $\mathrm{J} 1$ and $\mathrm{J} 2, \mathrm{~J} 1$ and $\mathrm{J} 3$, and $\mathrm{J} 2$ and $\mathrm{J} 3$ (Fig. 7).

The Karse rockslide (Fig. 2, L34) is located to the east of the Karse village (Fig. 2), on the left side of the confluence of the Rewati Khola and Shankar Khola. The rocks exposed on the slide are highly weathered slates and phyllites (Benighat Slate).

The Kuchur landslide (Fig. 2, L40) is a reactivated soil slide and is located on the southern part of the Kuchur village (Fig. 2, Plate 2). At the toe and in the middle part of the slide, the rocks of the Benighat Slate are exposed. At the crown, the land is tilted towards the uphill side, indicating recent movements along the slip surface.

The Kudule rockslide (Fig. 2, L47) is on the right bank of the Lothar Khola, near the Lothar Bridge. It lies in the upper part of the Lower Siwaliks consisting of fresh to slightly weathered sandstones and mudstones. The slide is a combination of plane failure along the bedding (B) and wedge failure along the intersections of the joint sets $\mathrm{J} 1$ and $\mathrm{J} 3, \mathrm{~J} 1$ and $\mathrm{B}$, and J3 and B (Fig. 7).

\section{Bank Undercutting}

Bank undercutting was quite distinct among other erosional processes in the Lothar Khola watershed. It was extensive along the lower reaches of the Ganwarchok Khola, Imti Khola, Pangthali Khola, and Rewati Khola as well as along the middle reaches of the Lothar Khola near Tadi Damar and around Karse (Fig. 2). As the rivers in the region are in their young stage, the adjacent slopes are steep. Bank undercutting is very intense during the heavy rainfall, as the erodibility of rivers is increased significantly by the presence of a huge amount of bed load. Similarly, when the flood enters a narrow gorge with a very small cross-sectional area, its velocity increases by many times. Consequently, the gorge is overflooded and overbank deposits are washed away.

\section{Sheet Erosion}

Sheet erosion was intense during the hours of high intensity rainfall. As the heavy rainfall lasted only for a few hours, it is believed that the surface (sheet) erosion played a minor role. Based on the preliminary field assessment, the depth of erosion was about $2 \mathrm{~mm}$ in the dry cultivated land, barren land, and grassland.

\section{Gully Erosion}

Gully erosion was severe in the upper part of the watershed. The first order streams of the Kali Khola, Janmang Khola, Mairang Khola, Bangsiling Khola, Yurti Khola, Rewati Khola, and Pangthali Khola suffered from gully erosion (Fig. 2). Severe gully erosion (1-3 m deep) was found on loose soils without vegetation cover and on highly weathered rock slopes.

\section{Debris Flows}

Debris flows occurred mainly in the upper sections of the Janmang Khola, along the Mairang Khola, and also at Sarling, Lorang, Dihitar, Piple, Campa, Sunachuli, and Loling. It was the most widespread phenomenon in the study area, especially in the region with colluvial cover and sparse vegetation. Owing to the high intensity rainfall, the terrain composed of loose rock and soil became saturated with water. The debris flow occurred when the saturated material on steep slopes lost its shear strength.

\section{CONCLUSIONS}

In the study area the rocks of the Raduwa Formation (an alternation of micaceous schists and quartzitic schists), Kalitar Formation (slates, phyllites, and meta-sandstones), and Kulikhani Formation (an alternation of micaceous schists and quartzitic schists), and the Siwalik Group (mudstones, sandstones, and conglomerates) are observed. The general dip of rock beds is due NE and the faults run along NW-SE. The rock mass is ramified by various discontinuities. Besides the bedding and foliation, from two to four joint sets are found. The joint spacing varies from a few $\mathrm{cm}$ to tens of $\mathrm{cm}$ in slates and phyllites, and from tens of $\mathrm{cm}$ to a few $\mathrm{m}$ in the quartzites. The joints are open owing to percolation of water and penetration of residual soils. 


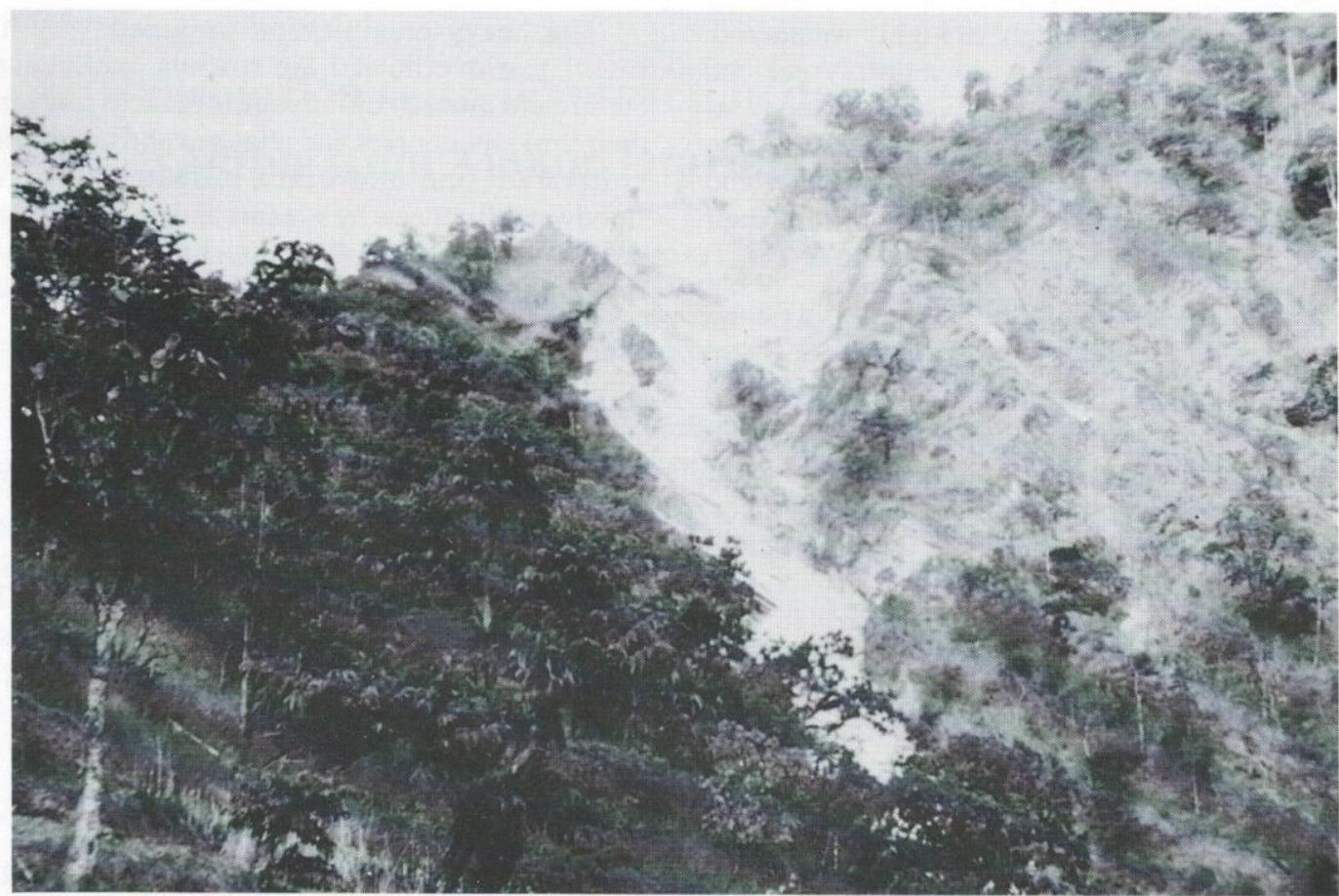

Plate 1: The Purbangkhani rockslide is located on the upper reaches of the Janmang Khola, near the Sarling village. View towards the northwest.

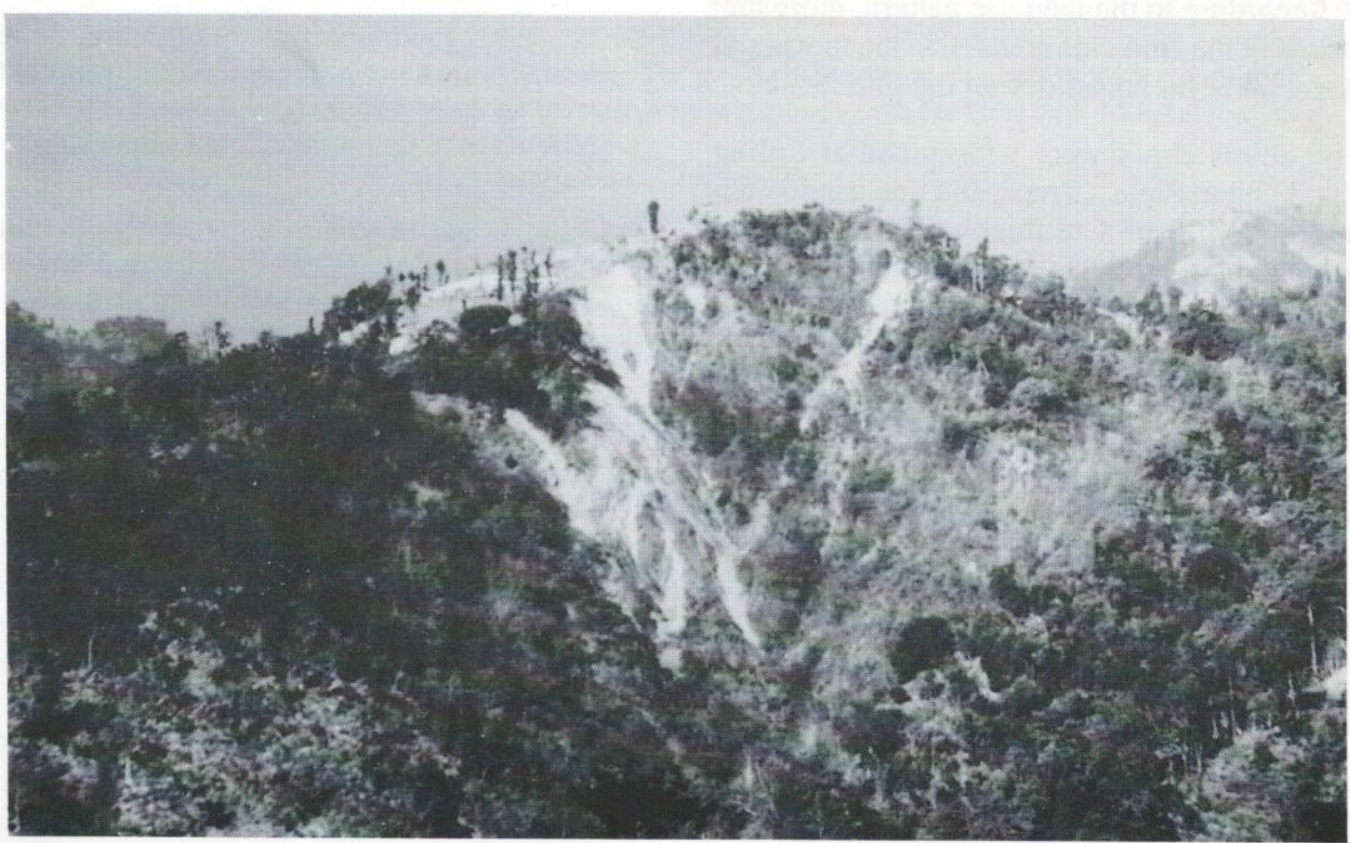

Plate 2: The reactivated Kuchur landslide at the Kuchur village, on the right bank of the Lothar Khola. View towards the west. 


\section{Dangol and P.D. Ulak}

The rocks are moderately to highly weathered. Phyllites, slates, and schists weather deeply and tend to form thick residual soils. The thickness of weathered zone is generally more than $5 \mathrm{~m}$. These rocks are potentially weak, and translational and rotational slides occur on them often within their parental residual soils.

There were more than 40 landslides in the watershed. Large rockslides were located at Sarling, Karse, and Loling. Most of them were reactivated during the downpour. Plane rockslides were especially common on dip-slopes, whereas wedge failures were observed mostly on counter dip slopes. The plane rockslides were generally large in comparison with the wedge failures.

The slopes ranging from 26 to $40^{\circ}$ were most affected by landslides. In those areas, the slope angle was nearly equal to or a little higher than the internal friction angle of soil or rock mass. Consequently, a little change in the slope and/or soil properties was enough to cause slides. Rockslides were most common (about $53 \%$ of the total rockslide area) on slopes covered by slates and phyllites. Most of the soil slides (more than $85 \%$ of the total soil slide area) occurred on residual soils. According to the land use pattern, more than two thirds of the landslide area fell in the forestland, and there were no landslides on the grassland.

The debris flows were widespread at Loling, Lorang, Dihitar, Piple, Campa, and Sunachuli. They deposited from 2 to $4 \mathrm{~m}$ thick sediments. On the other hand, from 1 to $3 \mathrm{~m}$ deep removal of sediments was observed in areas with intense gully erosion.
The heavy precipitation provided very high runoff that overflowed the streams, consequently the streams moved considerable distances away from their previous courses and attacked and undermined cultivated land and other infrastructure. The floodwater from nearby streams and gullies undercut the toe of the slope deposits. As the velocity of running water was very high, all the finer material was transported into the main channel.

\section{ACKNOWLEDGMENTS}

The authors express their sincere thanks to the Water Induced Disaster Prevention Technical Centre (DPTC) for the financial support to study the region and for the permission to publish this paper. They are also grateful to Dr. M. R. Dhital, Central Department of Geology, Tribhuvan University, for his valuable suggestions.

\section{REFERENCES}

DHM, 1993, Climatological Records of Nepal, 1963-1993 Department of Hydrology and Meteorology, Ministry of Water Resources, Nepal.

DMG, 1984, Geological Map of Central Nepal.

DPTC, 1995, Preliminary study of debris flows and landslides induced by the disaster of July 1993 in the watersheds of Lothar Khola, East Rapti River and Marin Khola. Kathmandu, Nepal, 164+ pp. (unpubl. Report)

Stöcklin, J. and Bhattarai, K. D., 1981. Geology of Kathmandu area and Central Mahabharat range, Nepal Himalaya. UNDP, New York, 64 pp. (unpubl. report) 